\title{
Modeling the effect of snow and ice on the global environmental fate and long-range transport potential of semi-volatile organic compounds
}

\author{
Doctoral Thesis \\ Author(s): \\ Stocker, Judith \\ Publication date: \\ 2007
}

Permanent link:

https://doi.org/10.3929/ethz-a-005361851

Rights / license:

$\underline{\text { In Copyright - Non-Commercial Use Permitted }}$ 
Diss. ETH No. 17086

Modeling the effect of snow and ice on the global environmental fate and long-range transport potential of semi-volatile organic compounds

\author{
A dissertation submitted to the \\ SWISS FEDERAL INSTITUTE OF TECHNOLOGY \\ for the degree of \\ Doctor of Natural Sciences
}

presented by

Judith Stocker

Dipl. Umwelt-Natw. ETH

MAS MTEC ETH/BWI

born on July 24, 1974

citizen of Abtwil, AG

accepted on the recommendation of

Prof. Dr. Konrad Hungerbühler, examiner

PD Dr. Martin Scheringer, co-examiner

Dr. Michael Lehning, co-examiner 


\section{Abstract}

It is known from field and modeling studies that snowfall events and the presence of snow covering soil and vegetation affect the environmental distribution of chemicals. Therefore, it is essential to understand how chemicals interact with snow and ice and how they are transported to cold regions. The latter is especially important in the context of today's chemicals politics aiming to reduce trans-boundary pollution and to protect remote regions against chemical contamination. Persistent organic pollutants and other semi-volatile organic compounds (SOCs) that were measured in snow and ice samples include polychlorinated biphenyls (PCBs), polycyclic aromatic hydrocarbons (PAHs) and polybrominated diphenyl ethers (PBDEs) as well as current-use pesticides such as dacthal, chlorpyrifos and endosulfan and historic-use pesticides including DDT, hexachlorobenzene (HCB) and $\alpha$-hexachlorocyclohexane $(\alpha-\mathrm{HCH})$.

Multi-media fate and transport models are a useful tool to investigate mechanisms and pathways of long-range transport (LRT) and environmental distribution of chemicals. They can thus be applied to investigate the fate of chemicals in snow and ice and the LRT of chemicals to cold environments. But so far, none of the existing global multi-media box models includes snow or ice compartments. In this work, we present a description of snow and ice implemented in the global multi-media model CliMoChem (Climate Zone Model for Chemicals). Processes describing the removal of chemicals from air to snow and surface ice include deposition of chemicals by wet and dry particle deposition, vapor scavenging by snow and dry gaseous deposition. Deposited chemicals are removed from snow and surface ice by re-volatilization, melt water runoff from surface ice or snow to soil and water, transfer from surface ice to deep ice and degradation in snow or surface ice. Investigated compounds include HCB, PCB28, PCB153, PCB180, PBDE47, PBDE209, $\alpha-\mathrm{HCH}$ and dacthal.

For snow, the relative importance of each deposition pathway depends on the chemical's affinity for snowflakes and particles in air whereas the chemical's affinity for bulk snow and melt water as well as the average air temperature are the main parameters influencing the removal pathways from snow. Investigated chemicals are mainly 
deposited to ice by vapor scavenging by snow or by particle deposition; transfer to deep ice is their main removal pathway from ice.

The presence of snow and ice alters the mass balance of the investigated chemicals in air, water, soil and vegetation by (i) enhanced re-volatilization due to the small storage capacity of the snow compartment, (ii) filtering of chemicals from the atmosphere by vapor scavenging by snow, (iii) transport of chemicals from air to soil or water by snowmelt and (iv) inhibition of the exchange between air and snow-covered compartments. In low latitudes, snow acts as a transfer medium taking up chemicals from air and releasing them to water or soil. The presence of snow in low latitudes increases the mass of investigated chemicals in soil by a factor of 1.1 (PBDE209) to 1.5 (PCB28). In high latitudes, snow and ice shield the covered compartments from chemical deposition. In the model version including snow and ice (scenario 2), the mass of investigated chemicals in soil in high latitudes is between $27 \%(\mathrm{HCB})$ and $97 \%(\alpha-\mathrm{HCH})$ of the mass calculated with the model version without snow and ice (scenario 1 ). In scenario 2 , the mass in vegetation in high latitudes reaches $8 \%(\alpha-\mathrm{HCH})$ to $15 \%$ (PCB28) of its value calculated in scenario 1 . The amount of chemical in Arctic water in scenario 2 achieves $8 \%(\alpha-\mathrm{HCH})$ to $21 \%$ (dacthal) of the amount obtained in scenario 1 . For all investigated chemicals except $\alpha-\mathrm{HCH}$, the inclusion of snow and ice in model calculations increases the amount of compound in air by a factor of 1.6 (HCB) to 10.8 (PBDE209) when compared to scenario 1 . The presence of snow and ice thus considerably changes the environmental partitioning of chemicals.

In the sensitivity analysis, transfer velocity to deep ice, degree-day factor in snow and organic carbon content in snow were identified as the most influential input parameters for the model output. The sensitivity of the basic model output towards snow and ice parameters is different for different chemicals and reflects their main deposition and removal pathways to and from snow and surface ice, respectively. 


\section{Zusammenfassung}

Aus Feld- und Modellstudien ist bekannt, dass die Verteilung von Chemikalien beeinflusst wird durch Schneefall und die Präsenz einer Schnee- oder Eisdecke. Deshalb ist es wichtig, zu verstehen, wie Schadstoffe mit Schnee und Eis interagieren und wie diese Stoffe in kalte Klimazonen transportiert werden. Letzteres ist im Kontext der aktuellen Chemikaliengesetzgebung besonders wichtig. Diese zielt darauf ab, den weiträumigen, grenzüberschreitenden Transport von Chemikalien in der Luft zu reduzieren und so entlegene Gebiete vor Kontamination durch Schadstoffe zu schützen. Persistente organische Substanzen und andere semi-volatile organische Verbindungen, die in Schnee- und Eisproben gemessen wurden sind u.a. polychlorierte Biphenyle (PCBs), polyaromatische Kohlenwasserstoffe (PAHs), polybromierte Diphenylether (PBDEs) sowie Pflanzenschutzmittel wie Dacthal, Chlorpyrifos, Endosulfan, DDT, Hexachlorobenzen (HCB) und $\alpha$-Hexachlorocyclohexan $(\alpha-\mathrm{HCH})$.

Modelle, welche den globalen Schadstofftransport in verschiedenen Klimazonen und Umweltkompartimenten beschreiben, helfen, den weiträumigen Transport sowie die Verteilung der Chemikalien zwischen den einzelnen Kompartimenten abzubilden. Diese Modelle sind somit wichtige Instrumente, um das Verhalten von Schadstoffen in Schnee und Eis zu untersuchen und die Transportmechanismen zu verstehen, die für das Vorkommen von Schadstoffen in entlegenen schnee- und eisbedeckten Regionen verantwortlich sind. Keines der gängigen globalen multi-kompartiment Modelle enthält jedoch Schnee- oder Eiskompartimente. Im Rahmen der vorliegenden Arbeit wurden deshalb Schnee und Eis als neue Medien in ein bestehendes globales Umweltmodell eingefügt. Beim Modell handelt es sich um das globale, dynamische multi-kompartiment Modell CliMoChem. Der Einfluss von Schnee und Eis auf die globale Verteilung und den weiträumigen Transport wurde anhand folgender Chemikalien untersucht: HCB, PCB28, PCB153, PCB180, PBDE47, PBDE209, $\alpha-\mathrm{HCH}$ und Dacthal.

Die Deposition von Chemikalien von Luft auf Schnee oder Eis wird durch die Prozesse Diffusion, Auswaschung durch Schneeflocken sowie trockene und nasse Partikeldeposition beschrieben. Deponierte Chemikalien re-volatilisieren, werden abgebaut, mit dem Schmelzwasser wegtransportiert oder, im Fall von Eis, in tieferen Eisschichten 
eingelagert. In Schnee bestimmen die Affinitäten der Chemikalien für Schneeflocken und Partikel in der Luft, welcher der oben genannten vier Depositionspfade überwiegt; die Affinität der Substanzen für das Schneekompartiment und für Schmelzwasser bestimmen neben der Lufttemperatur die Relevanz der einzelnen Verlustprozesse. Auswaschung mit Schnee und Partikeldeposition sind die wichtigsten Pfade der Deposition der untersuchten Chemikalien auf Eis. In CliMChem werden die auf Eis deponierten Chemikalien vorwiegend in tieferen Eisschichten eingelagert.

Schnee und Eis beeinflussen kurz- und langfristige Trends von semi-volatilen organischen Verbindungen in den unterschiedlichen Umweltkompartimenten des Modells. Die Massenbilanzen der untersuchten Chemikalien in Luft, Wasser, Boden und Vegetation ändern sich aufgrund (i) verstärkter Re-volatilisierung wegen der geringen Speicherkapazität des Schnees, (ii) verstärkter Auswaschung der Chemikalien durch Schneefall, (iii) des Schmelzwassertransports der Chemikalien in den Boden und ins Wasser und (iv) blockierter Chemikaliendeposition von Luft auf schnee- oder eisbedeckte Kompartimente. Schnee in niederen Breitengraden fungiert als Transfermedium, welches Chemikalien aus der Luft aufnimmt und in den Boden oder ins Wasser abgibt. In niederen Breitengraden erhöht die Schneeschmelze die Masse der untersuchten Chemikalien im Boden um einen Faktor von 1.1 (PBDE209) bis 1.5 (PCB28) im Vergleich zu den Resultaten, die mit der Modelversion ohne Schnee und Eis (Szenario 1) berechnet wurden. In höheren Breitengraden schützen Schnee und Eis die darunter liegenden Umweltmedien vor Chemikaliendeposition aus der Luft. In der Modelversion mit Schnee und Eis (Szenario 2) erreicht die Masse der Chemikalien in Böden höherer Breitengrade $27 \%(\mathrm{HCB})$ bis $97 \%(\alpha-\mathrm{HCH})$ der kalkulierten Masse in Szenario 1. In Szenario 2 repräsentiert die Masse in der Vegetation höherer Breitengrade $8 \%(\alpha-\mathrm{HCH})$ bis $15 \%$ (PCB28) der in Szenario 1 berechneten Substanzmenge. In der Arktis wird die Menge der Chemikalien in Wasser in Szenario 2 auf $8 \%(\alpha-\mathrm{HCH})$ bis $21 \%$ (dacthal) der in Szenario 1 berechneten Masse verringert. Ausser für $\alpha-\mathrm{HCH}$ erhöht sich die Substanzmenge in Luft für alle untersuchten Chemikalien in Szenario 2 um einen Faktor von 1.6 (HCB) bis 10.8 (PBDE209) im Vergleich zu Szenario 1. Schnee und Eis beeinflussen folglich wesentlich die Verteilung der untersuchten Chemikalien in den einzelnen Umweltmedien.

Die folgenden drei Inputparameter wurden im Rahmen der Sensitivitätsanalyse als besonders wichtige Parameter identifiziert: (i) die Geschwindigkeit, mit der auf Oberflächeneis deponierte Chemikalien in das darunter liegende Tiefeis transportiert werden, (ii) der so genannte Degree-day Faktor und (iii) der Gehalt an organischem Material im Schnee. Die Sensitivität des Modells gegenüber Schnee- und Eisparametern ist unterschiedlich für unterschiedliche Chemikalien je nach Relevanz ihrer einzelnen Depositions- und Verlustprozesse in Schnee und Oberflächeneis. 